\title{
Drinking water pollutants may affect the immune system: concerns regarding COVID-19 health effects
}

\author{
Natalia Quinete $^{1}$ (D) Rachel Ann Hauser-Davis ${ }^{2}$ \\ Received: 22 May 2020 / Accepted: 30 October 2020 / Published online: 6 November 2020 \\ (C) Springer-Verlag GmbH Germany, part of Springer Nature 2020
}

\begin{abstract}
The current coronavirus pandemic is leading to significant impacts on the planet, changing our way of life. Although the COVID19 virus mechanisms of action and pathogenesis are still under extensive research, immune system effects are evident, leading, in many cases, to respiratory distress. Although apparent pollution reduction has been noticed by the population, environmental and human health impacts due to the increased use of plastic waste and disinfectants is concerning. One of the main routes of human exposure to pollutants is through drinking water. Thus, this point of view discusses some major contaminants in drinking water known to be immunotoxic, exploring sources and drinking water routes and emphasizing the known mechanisms of action that could likely compromise the effective immune response of humans, particularly raising concerns regarding people exposed to the COVID-19 virus. Based on a literature review, metals, plastic components, plasticizers, and per- and polyfluoroalkyl substances may display the potential to exacerbate COVID-19 respiratory symptoms, although epidemiological studies are still required to confirm the synergistic effects between these pollutants and the virus.
\end{abstract}

Keywords SARS-CoV-2 $\cdot$ Immune response $\cdot$ Cytokines $\cdot$ PFAS, plastic components and plasticizers $\cdot$ Metals

\section{Introduction}

The current coronavirus pandemic is resulting in huge impacts worldwide in many aspects. With social distancing and mandatory self-quarantines in order to avoid the spread of the novel COVID-19 coronavirus and, consequently, relieve the burden of the healthcare system to save lives, the population has been falsely convinced that there have been environmental benefits with decreased environmental pollution. In fact, in very industrialized countries and cities, clear skies and more wildlife roaming the streets and in rivers have been spotted, as the pandemic has led to decreased car and flight transit, as well

Responsible editor: Philippe Garrigues

Natalia Quinete

nsoaresq@ fiu.edu

1 Institute of Environment \& Department of Chemistry and Biochemistry, Florida International University, 11200 SW 8th Street, Modesto A. Maidique Campus, Miami, FL 33199, USA

2 Laboratório de Avaliação e Promoção da Saúde Ambiental, Instituto Oswaldo Cruz, Fiocruz, Av. Brazil, 4.365, Manguinhos, Rio de Janeiro, RJ 21040-360, Brazil as the shutdown of industries and commerce, forcing people to stay at home (National Geographic 2020). However, the COVID-19 pandemic, in reality, has been causing major drawbacks in terms of environmental protection policies around the globe. For example, the United States Environmental Protection Agency (U.S. EPA) has stopped enforcements concerning monitoring and reporting requirements of environmental protection for an undefined period of time, China has temporarily suspended environmental regulations, and Brazil has reduced surveillance on environmental compliance in the Amazon Rainforest (Forbes 2020). At the same time, the fear associated with COVID-19 transmission has resulted in increased use of single-use plastics, disinfecting products and related chemicals, therefore causing increased environmental water pollution concerns. Single-use plastics are now more popular than ever as, amid the COVID19 fear, people will preferentially buy disposable items like water bottles and other products housed in plastic containers and bags, such as hand sanitizers, sanitizing wipes, toilet papers, cleaning products and tissues, and food items.

The current situation has been even more aggravated since recycling companies and the plastic collection points of 100,000 retailers worldwide have ceased operations, not only due to health and safety concerns, but also for financial 
reasons, with the costs concerning gathering the waste and processing higher than simply producing more plastic (Haultail 2020). In addition, since 2018, China and other countries have stopped accepting millions of tons of recyclable materials and waste from the USA for processing, which leads to major waste management issues in the country (Huffpost 2018).

Governments worldwide have taken precautionary measurements to reduce COVID-19 infections. In Surabaya, Indonesia, one of the responses to the coronavirus pandemic was a drone dispersing clouds of disinfectant in the sky above the city (Wardoyo and Geddie 2020). Although COVID-19 is a contagious respiratory disease that spreads through droplets from the nose or mouth via coughing or sneezing, this type of approach could be even more toxic to people, since disinfectants such as bleach and glutaraldehyde have been reported as leading to higher risks for the development of progressive lung diseases (Svanes et al. 2018; Dumas et al. 2019) and do not necessary improve virus containment.

Studies on COVID-19 transmission and mode of actions are still very incipient to draw any definitive conclusions, but reports have shown that older adults and people with previous underlying medical conditions like lung or heart disease or diabetes seem to be at higher risk for developing more serious complications from this disease (Onder et al. 2020; Zhou et al. 2020).

One of most recent explanations of the deadly effects of COVID-19 is associated to its immune system effects, in a phenomenon broadly known as "cytokine storm," where the immune system releases a large number of cytokines, which attack the organs they were intended to protect (Shi et al. 2020). The effects of this immune system overreaction can lead to fatal outcomes due to complications such as lung inflammation, pneumonia, and respiratory issues.

Numerous contaminants are present in the aquatic system, and many of these are frequently found in our drinking water and are known carcinogenic and immune suppressors, raising concerns on the health effects associated with the new coronavirus. Therefore, this manuscript identifies the major inorganic and organic pollutants found in drinking water that have been associated to adverse immune system effects, exploring human exposure routes and mode of action on the immune system, addressing concerns regarding the potential health impacts on people exposed to COVID-19. The health risks associated with extensive use of disinfectants and cleaning products are also discussed.

\section{Major inorganic and organic water pollutants known to affect the immune system}

Due to the finite nature of the world's fresh water sources, water quality is of utmost concern. Expanding populations allied to continued growth in the manufacturing, pharmaceutical, and chemical sectors increase the potential for exposure to a diversity of chemical compounds through air, food and, especially, water. Access to clean water is crucial in our daily lives, from water used to wash our food, to showering, swimming, and drinking. Drinking water pollution is not recent or new and has been linked to several water-borne diseases (Levantesi et al. 2012; Luby et al. 2015) and may result in autoimmune diseases in humans (Leffel et al. 2003). Common drinking water pollutants include metals, such as arsenic, lead, and mercury, and organic chemicals like poly and per- and polyfluoroalkyl substances (PFAS) and phthalates, as well as microbes and cysts.

While water treatment plants are capable of eliminating some of these pollutants, others are poorly removed and may contaminate drinking water. Growing concerns are noted, especially regarding emerging contaminants with endocrine disrupting properties, which can mimic, block, or interfere with hormones, producing adverse developmental, reproductive, neurological, and immune effects in both humans and wildlife (Diamanti-Kandarakis et al. 2009). Herein, we will focus on selected pollutants considered major contaminants in drinking water which are expected to show increased levels during and after the COVID-19 pandemic and result in adverse effects to the immune system. Contaminants such as chlorinated hydrocarbons, although also major water pollutants, are not expected to increase during the pandemic, as fewer agricultural activities are being carried out, due to human exposure concerns regarding the coronavirus, and were, thus, not included.

\section{Metals}

Among the metals regularly monitored in public water supplies and with established maximum contaminant levels determined by the U.S. EPA in drinking water, arsenic (As), cadmium $(\mathrm{Cd})$, chromium $(\mathrm{Cr})$, lead $(\mathrm{Pb})$, and copper $(\mathrm{Cu})$ have been identified as pollutants of concern, posing a serious threat to human health.

The most ubiquitous of the toxic metals in drinking water is $\mathrm{Pb}$. $\mathrm{Pb}$, as well as $\mathrm{Cu}$, can leach from water pipes and soldered joints in either the distribution system or individual houses, being an issue especially in homes with older infrastructure (ATSDR 2002; Makris et al. 2014). Pb exposure has been associated with a wide range of adverse effects in humans, including blood disorders in adult and children (Farzan et al. 2018), gastrointestinal distress, decreased neurological functioning, heart and kidney diseases (IARC 2006; WHO 2011a), and immune function alterations, especially in young children (Goebel et al. 2000; Li et al. 2005; Chakrabarty and Sarma 2011). The EPA's maximum contaminant level (MCL) for $\mathrm{Pb}$ is $0.005 \mathrm{mg} \mathrm{L}^{-1}$ in water. However, several studies have indicated that $\mathrm{Pb}$ exposure has negative human health impacts 
even at very low levels and that there is no safe threshold value for this contaminant in drinking waters (Haefliger et al. 2009; Wang et al. 2019). Exposure to $\mathrm{Cu}$, even at low doses, has been correlated to mutagenesis, carcinogenicity, infertility, and immune suppression (Kvietkauskaite et al. 2004; Markevičius and Dringeliene 2004). The MCL for $\mathrm{Cu}$ in drinking water is $1.3 \mathrm{mg} \mathrm{L}^{-1}$.

As is used industrially as an alloying agent, as well as in the processing of glass, pigments, textiles, paper, metal adhesives, wood preservatives, in pesticides, feed additives, and pharmaceuticals (NRC 1999; Flanagan et al. 2012). The greatest threat to public health from inorganic As originates from contaminated groundwater and drinking water, where high levels have been observed in several countries, including Argentina, Bangladesh, Chile, China, India, Mexico, and the USA (NRC 1999; Flanagan et al. 2012). Exposure to As is associated to adverse effects during pregnancy and infant mortality and negative impacts on cognitive development, diabetes, pulmonary and cardiovascular disease, cancers, heart attacks, and kidney failure (Farzan et al. 2013; Tolins et al. 2014; Quansah et al. 2015). The effect of As in the immune system has been demonstrated in many studies, including increased risk of respiratory infections (Rahman et al. 2011; Cardenas et al. 2015, 2018; Farzan et al. 2016, 2018). The MCL for As in drinking water is $0.010 \mathrm{mg} \mathrm{L}^{-1}$.

Contamination of drinking water may occur as a result of the presence of $\mathrm{Cd}$ as an impurity in the $\mathrm{Zn}$ of galvanized pipes or cadmium-containing solders in fittings, water heaters, water coolers, and taps (WHO 2011b). Human exposure to Cd could cause organ system failure, bone, and cardiovascular system damage, renal toxicity, neurotoxicity, diabetes, and cancer (Satarug et al. 2010), as well as immune system impacts (Skoczyńska et al. 2002). The MCL for Cd in drinking water is $0.005 \mathrm{mg} \mathrm{L}^{-1}$.

$\mathrm{Cr}$ and its salts are used in mining, chrome plating, cement production, leather tanning, detergents, pigments and paints, photography, fungicides, in the ceramic and glass industry, and for corrosion control (WHO 2003). Solid wastes from chromate-processing facilities, when disposed of improperly in landfills, can be groundwater contamination sources, with a $\mathrm{Cr}$ residence time of several years (WHO 2003). Cr(VI) and $\mathrm{Cr}(\mathrm{III})$ are the most stable oxidation states of this element. While $\mathrm{Cr}(\mathrm{III})$ is a proposed essential nutrient, $\mathrm{Cr}(\mathrm{VI})$ is predominantly produced during industrial activities. The presence of $\mathrm{Cr}(\mathrm{VI})$ in drinking water sources is of health concern, since exposure to $\mathrm{Cr}(\mathrm{VI})$ has been known to adversely affect the liver and kidney, the respiratory and alimentary tracts, and the hematological and immune systems (Shrivastava et al. 2002; Wilbur et al. 2012; Shipkowski et al. 2017), leading to its classification as a carcinogenic compound (Bucher 2007). The MCL for $\mathrm{Cr}$ in drinking water is $0.05 \mathrm{mg} \mathrm{L}^{-1}$.

\section{PFAS}

PFAS, also known as forever chemicals, have been categorized as compound classes of increasing concern regarding drinking water exposure. Their unique chemical properties, comprising persistence, resistance, and their ability as water and oil repellents, make these substances commercially attractive, with several applications used in consumer products, including surfactants, water repellents sprays, lubricants, adhesives, additives and coatings, paints, and firefighting foams (Prevedouros et al. 2006; Schaider et al. 2017). They are, therefore, found in food packaging, non-stick products, stain-repellent clothing, cleaners, and many other household items. Groundwater contamination near military bases and airports due to the use of firefighting foams is of great concern and considered one of the major sources of PFAS (Moody and Field 2000; Hu et al. 2016).

Due to their amphiphilic properties, and preferential binding to proteins, PFAS have been found to be the most prevalent contaminants in human blood (Kannan et al. 2004) and wildlife worldwide (Keller et al. 2005; Francis et al. 2008; Quinete et al. 2009), presenting clear potential hazards to human health. Human exposure to PFAS can occur through food and water ingestion, dust inhalation, and hand-to-mouth transfer from contaminated area (Crone et al. 2019; Sunderland et al. 2019). Studies have shown that human PFAS exposure has been linked to elevated cholesterol, obesity, cancer, developmental delays, thyroid disease, and infertility and immune suppression in children (Ganesan and Vasudevan 2015; Pennings et al. 2016; Sunderland et al. 2019). More recently, De Toni et al. (2020) observed increased cardiovascular risks associated with chemical sensitivity to perfluorooctanoic acid (PFOA), therefore suggesting that increased PFOA levels in the blood may lead to cardiovascular diseases. It is important to highlight that after the phase down of the production of "legacy" PFAS, PFOA and perfluorooctane sulfonate (PFOS), which have replaced these compounds, are still poly or per-fluorinated compounds, presenting shorter chains or the insertion of ester functional groups (Clara et al. 2009) and a major gap concerning the understanding of the toxicity effects and pathways of these compounds in humans, and the environment is clear. The U.S. EPA's lifetime health advisory limit in drinking water for PFOS and PFOA is of $70 \mathrm{ng} \mathrm{L}^{-1}$ (EPA 2009).

\section{Plasticizers and plastic components (phthalates and bisphenols)}

Phthalates and bisphenol A (BPA) are commonly called "everywhere chemicals," as they are common in the countless plastic products of daily use (Trivedi et al. 2020).

Phthalates are chemicals of emerging concern widely used as plasticizers and additives in many consumer products, 
including pharmaceuticals, cosmetics, personal care, medical and building materials, food packing, detergents, and children's toys (Schettler et al. 2006; National Resarch Council 2008). They are also used as solvents and lubricants and are found in many spray products, such as pesticides, fragrance products, and hairspray, among others. These phthalic acid esters are lipids with different alkyl groups that present varying hydrocarbon chain lengths, making them poorly soluble in water, displaying slow degradation rates while, as additives, they are non-covalently bound to the material matrix, eventually reaching the surface and leaching from the product, resulting in environmental accumulation (Díaz Padín et al. 2019). These are the most common chemicals which humans are in contact with (Net et al. 2015), and exposure occurs mainly via ingestion, inhalation, dermal contact, contact with dust/soil, and parenteral administration (National Resarch Council 2008; Net et al. 2015; Wang and Kannan 2019). Previous assessments have associated phthalates with diabetes and insulin resistance (Stahlhut et al. 2007; Sun et al. 2014), overweight and obesity (Buser et al. 2014), allergy and asthma (Braun et al. 2013; Hoppin et al. 2013), anomalies in development and reproductive health (Duty et al. 2003; Frederiksen et al. 2012; Upson et al. 2013), hepatic and renal function, hepatic structure, thyroid signaling, immune function, and metabolic homeostasis (Rusyn et al. 2006; Wei et al. 2012; Shehata et al. 2013). The phthalate metabolites bis(2ethylhexyl) phthalate (DEHP) and benzyl butyl phthalate (BBP) have been classified as probable and possible human carcinogens, respectively, by the U.S. EPA (Wang and Kannan 2019). A maximum admissible concentration for DEHP in water of $8 \mu \mathrm{g} \mathrm{L}^{-1}$ and $6 \mu \mathrm{g} \mathrm{L}^{-1}$ was established by WHO and U.S. EPA, respectively (WHO 2004; EPA 2018a) (EPA 2009).

Bisphenol A (2, 2 bis(4-hydroxyphenyl) propane, BPA) is used in the manufacture of polycarbonate plastics present in many commonly used consumer goods, i.e., plastic containers, toys, water bottles, and baby pacifiers, among others. During use, this compound leaches from products, resulting in high human and animal exposure worldwide (McLachlan 2001; Rochester 2013). BPA is a endocrine disruptor, with the ability to bind to estrogen receptors and promote both agonist and antagonist activity (Hiroi et al. 1999). It also displays the ability to cross the placental barrier, which is of concern regarding developmental responses (Imanishi et al. 2003; Mørck et al. 2010), and appears to activate many immune pathways involved in both autoimmune disease development and autoimmune reactivity provocation (Kharrazian 2014).

Although BPA-containing products have slowly been taken of the market, due to endocrine disrupting concerns, replaced by analogs, such as bisphenol S (BPS), little is known about their immune effects, requiring further assessments $(\mathrm{Xu}$ et al. 2016).

\section{Exposure pathways: Route to drinking water and human exposure}

Drinking water is derived from either surface waters, comprising rivers, streams, wetlands and lakes, or groundwater, consisting of the water contained beneath the surface in rocks and soil accumulated underground in aquifers (Khublaryan 2009).

Several contaminants of public health importance are naturally occurring in these water bodies. For example, metals may originate from natural geochemical lithosphere conditions and geological processes, such as volcanic action, related hydrothermal activity, and weathering (Garrett 2000). Anthropogenic activities, however, have led to extensive contamination of both sources by thousands of chemical substances (Holt 2000; Howard et al. 2006), which may be released in many stages, including their extraction, manufacture, formulation, use, and end-user disposal or destruction (Holt 2000).

In general, urbanization and industrialization processes and agriculture and forestry activities are considered the two major contaminant inputs for these freshwater water bodies (Holt 2000). Contaminant sources from these inputs may be classified as point source pollution (PS), easily identified and confined locations, or non-point source pollution (NPS), resulting from many diffuse sources (EPA 2018b). The former comprises domestic sewage networks, industrial effluents, and accidental spills, while the latter consists of agricultural practices, scattered dwellings, atmospheric deposition, construction work, land run-off, and river transportation (EPA 2018b). Both result in differential contaminant discharges to water bodies, with PS usually consisting of direct discharges to water courses, while NPS may involve partial contaminant deposition before reaching the water course (Holt 2000). Is has been reported that NPS is the leading cause of water quality problems, as significant variations over time and space are usually noted, reflecting seasonal use patterns (Holt 2000; EPA 2018b).

Concerning sources of contamination, surface water contamination occurs mostly through direct or indirect emissions and groundwater can be contaminated by soil leaching (WHO 2016). Groundwater contamination, in particular, comprises a significant public health concern, as this is an important source of drinking water in many regions worldwide, many times the only one, constituting $97 \%$ of global freshwater (Howard et al. 2006).

Surface waters mainly contaminated by domestic and industrial sewage are treated by municipal water treatment plants (WTP). WTP are designed to remove conventional organic pollutants found in domestic and industrial wastes, although many lacks the capacity to remove several contaminants (Li 2014). This has, in fact, been recognized as the main introduction route for several contaminants into the aquatic 
environment, since they are not treatment targets (Ternes 1998; Bolong et al. 2009).

It is important to note that contaminant emission patterns and amounts vary among chemicals. For example, pharmaceutical production processes using intermediates release only small amounts into the environment, end-use products, such as household detergents are almost $100 \%$ released into public sewers, while chronic water body contamination is observed in the case of plastic components and plasticizers, due to leaching from plastic houseware and utensils, among others (Erythropel et al. 2014). It is also important to note that potable water supply treatment and the distribution system themselves may also result in contaminant inputs in drinking water, due to, for example, disinfection processes, which produce several toxic by-products (Holt 2000), and certain metals, i.e., lead, from brass plumbing and other distribution network materials; organotins, from polyvinyl chloride pipes and PAHs from older pipes, lined with coal tar pitch (Forsyth and Jay 1997; Elfland et al. 2010; WHO 2011c).

\section{Immune suppression effects of drinking water contaminants and COVID-19 concerns}

Common COVID-19 symptoms comprise fever, fatigue, respiratory symptoms, lymphopenia, and pneumonia, while some reports also indicate gastrointestinal symptoms (Chan et al. 2020; Gu et al. 2020; Huang et al. 2020; Prompetchara et al. 2020; Wu et al. 2020). Immune responses of infected patients have not yet been fully elucidated, although several studies have indicated that lymphopenia and "cytokine storms," a form of systemic inflammatory response syndrome, involving many specific inflammatory mediators, such as cytokines (i.e., IL-2, IL-7, IL-10, G-CSF, IP-10, MCP-1, MIP$1 \mathrm{~A}$, and $\mathrm{TNF} \alpha$, among others), which play a vital role in inflammatory reactions (Lee et al. 1994; Ramella et al. 2017), are also a major factor in the COVID-19 condition (Nicholls et al. 2003; Wong et al. 2004; Mahallawi et al. 2018; Shimabukuro-Vornhagen et al. 2018).

Many pollutants previously considered only in light of their endocrine disruption capability have recently also been implicated in the activation of several immune pathways involved in both autoimmune disease development and autoimmune reactivity provocation, as estrogen has also been reported as playing an important role in the immune system altering inflammatory mediator responses and humoral immune response (Lee et al. 1994; Yoshino et al. 2003; Haghmorad et al. 2014). These include contaminants such as metals; PFAS; plastic components, such as BPA; and plasticizers, like phthalates (Dong et al. 1998; Kharrazian 2014; Hansen et al. 2015), although studies are still incipient in this regard. Although many in vitro studies have demonstrated cytokine effects, among other immune responses by several pollutants
(Shertzer et al. 1985; Li et al. 2013), only assessments performed through the drinking water exposure route in mammals (mice, rats, rabbits) in laboratory conditions or concerning human cohorts are included herein.

\section{Metals}

Several studies have demonstrated that exposure to many metals, both toxic and essential, at both subchronic and chronic levels may result in immunotoxic effects, especially concerning cytokines. However, many assessments are performed in vitro, or when in mammals (mice, rats) through oral gavage or food pellet exposure, and drinking water exposure assessments are still scarce. In addition, the mechanisms responsible for these effects are still unclear.

In this context, the few assessments available in this regard all point to significant immunotoxic effects even at low doses. For example, exposure to lead $(\mathrm{Pb})$ and copper $(\mathrm{Cu})$ for 2 weeks through drinking water in has been reported as leading to alterations in the natural cytokine balance in BALB/c mice with free access to drinking water containing $\mathrm{Pb}$ and $\mathrm{Cu}$. The animals displayed upregulation of interferon-gamma (IFN- $\gamma$ ), a homodimeric glycoprotein produced by activated $\mathrm{T}, \mathrm{B}$, and NK cells, in the spleen of both treated groups, while interlukin-4 (IL-4), a TH2 cytokine secreted by activated TH2 and NKT cells and a potent inducer for of $\mathrm{CD}^{+}$naive $\mathrm{T}$ cell differentiation into $\mathrm{TH} 2$ effector cells, was only upregulated in the $\mathrm{Cu}$-treated group and downregulated in the $\mathrm{Pb}$-treated group $\mathrm{Pb}$. Thus, both $\mathrm{Pb}$ and $\mathrm{Cu}$ significantly altered natural cytokine balance, which may lead to negative immune effects (Radbin et al. 2014).

In another study, the effects of subchronic, oral, and lowdose cadmium (Cd) exposure $\left(32 \mathrm{mg} \mathrm{L}^{-1}\right.$ cadmium chloride in drinking water for 10 weeks on the rat immune system) were evaluated, and the results indicate that $\mathrm{Cd}$-exposed animals demonstrated slight increases in in regulatory $\mathrm{T}$ cells and significant increases in the production of IFN $\gamma$ and IL-10, suggesting that $\mathrm{Cd}$ exposure may affect multiple $\mathrm{T}$ cell subsets, impacting both immune cell function and cellularity, which may enhance inflammatory responses (Turley et al. 2019).

Regarding $\mathrm{Cr}$, it has been noted that only a few data are available on pro-inflammation assessments for this element. In one laboratory study, exposure to $50 \mathrm{mg} \mathrm{L}^{-1}$ or $200 \mathrm{mg} \mathrm{L}^{-1}$ in the drinking water of 5-week-old pubertal male ICR mice for 7 and 21 days led to significant increases in serum TNF $\alpha$ and IL- 6 in the $200 \mathrm{mg} \mathrm{L}^{-1}$ treatment at 7 days exposure and increases in mRNA cytokine levels, suggesting that $\mathrm{Cr}$ displays immunotoxicity potential by altering inflammatory responses (Jin et al. 2016). In a human cohort assessment, occupational chromate exposure led to significantly decreased IL-6, IL-10, IFN- $\gamma$, IL-17A, and IFN- $\gamma /$ IL-4, while significantly increased $\mathrm{C} 3$ and $\mathrm{C} 4$ expressions were observed. In addition, IFN- $\gamma, \operatorname{IgG}$, and $\operatorname{IgA}$ displayed an inverse 
association with whole blood $\mathrm{Cr}$, while $\mathrm{C} 3$ and $\mathrm{C} 4$ were positively associated with whole blood Cr, and both IL-10 and IL$17 \mathrm{~A}$ inversely associated with urine $\mathrm{Cr}$. The results indicate that occupational exposure to chromate could downregulate the cellular and humoral factors of the immune system (Qian et al. 2013).

Concerning As, rabbits exposed to $13 \mathrm{mg} \mathrm{L}^{-1} \mathrm{As}_{2} \mathrm{O}_{3}$ in drinking water for 6 months resulted in the increased expression of vascular cell adhesion molecule-1, IL-8, and IL-6, key molecules involved in inflammation, at the RNA and protein levels, implicating this element in inflammatory mechanisms (Ma et al. 2012). In one of the few assessments carried out in humans concerning arsenic (As) exposure through drinking water, the immunological status of children (90 individuals, aged 6-10 years, comprising 38 girls, 52 boys) exposed to arsenic through their drinking water was assessed. Increased incidences of asthma, allergies, and parasitic infections in individuals with high As levels in urine compared with those with As levels lower than the reference value in urine $\left(50 \mu \mathrm{g} \mathrm{L}^{-1}\right)$ were noted, and increased urine arsenic levels were associated to significantly inhibited IL-2 secretion levels. With these findings, the authors postulated that As exposure could alter $\mathrm{T}$ cell activation processes, leading to an immunosuppression status that would, in turn, favor opportunistic infections and carcinogenesis (Soto-Peña et al. 2006).

\section{PFAS}

Studies on PFAS immune effects are still scarce. One assessment evaluated developmental immunotoxic effects after maternal oral exposure through drinking water PFOS (perfluorooctane sulfonate) at $0.1,1.0$, and $5.0 \mathrm{mg}$ PFOS $\mathrm{kg}$ day $^{-1}$ during gestational days $1-17$ in C57BL/6 mice and reported that male pups were more affected than females since; an imbalance in TH1/TH2-type cytokines with excess TH2 cytokines (IL-4) was detected only in males at 8 weeks old, while hormone alterations were also noted, i.e., decreased serum testosterone levels and increased estradiol levels only in male pups. The authors postulate that testosterone-mediated endocrine function may be partially involved in the TH1/TH2imbalance induced by PFOS (Zhong et al. 2016). In another assessment, NOD mice were exposed to perfluoroundecanoic acid (PFUnDA) through drinking water at 3, 30, and $300 \mu \mathrm{g} \mathrm{L}^{-1}$ at mating, during gestation, and lactation and until 30 weeks of age. Altered cytokine secretion, namely INF $\gamma$, TNF $\alpha$, IL-1 $\beta$, IL-2, IL-4, IL-6, IL-10, IL-13, and IL-17, in activated splenocytes was noted after exposure to $3 \mu \mathrm{g} \mathrm{L}{ }^{-1}$ PFUnDA. The authors hypothesized that the observed differences in cytokine secretion at different exposure doses could indicate a non-monotonic dose response, with different receptor activations or different receptors being activated at different exposure levels (Bodin et al. 2016).
Other assessments have also reported cytokine alterations, such as the study carried out by Fair et al. (2011), who exposed female $\mathrm{B}_{6} \mathrm{C}_{3} \mathrm{~F}_{1}$ mice to PFOS through drinking water for 28 days at total $0,0.1,0.5,1$, or $5 \mathrm{mg}$ PFOS kg ${ }^{-1}$ doses and noted significantly increased IL- 6 production by $\mathrm{B}$ cells, and the assessment was performed by Zheng et al., who exposed adult male C57BL/6 mice to PFOS for 7 days and noted reduced Th1 cytokine (IL-2 and INF $\gamma$ ) secretion in favor of Th2 cytokines (IL-4, IL-10) (Zheng et al. 2011). The latter authors indicated that a host's immune state is likely to be characterized by a shift toward $\mathrm{T}(\mathrm{H}) 2$-like state which may lead to cellular response suppression and humoral response enhancement following a high-dose short-term exposure to PFOS. In humans, several PFAS have been directly associated to asthma diagnosis or severity and number of common cold episodes, as well as reduced seroprotection from the influenza A H3N2 virus and higher IL-4 and IL-5 T-helper cytokine levels in humans (Dong et al. 2013; Granum et al. 2013; Humblet et al. 2014; Looker et al. 2014; Zeng et al. 2015; Zhu et al. 2016) while the upregulation of immunomodulatory genes has been associated with a range of prenatal PFAS exposure (Pennings et al. 2016).

\section{Plasticizers and plastic components (phthalates and bisphenols)}

In vivo assessments regarding exposure to drinking water in laboratory conditions are extremely scarce for phthalates. In one of the few evaluations carried out in this regard, BALB/c mice were exposed to butyl benzyl phthalate (BBP), a parent compound of the phthalate metabolite mono- $n$-butyl phthalate (MnBP) at $3 \mathrm{mg} \mathrm{mL}^{-1}$ exclusively through drinking water for different time periods. Maternal exposure to BBP resulted in airway inflammation in the offspring, up to the F2 generation, mediated by BBP-induced DNA hypermethylation. $\mathrm{CD} 4^{+} \mathrm{T}$ cell function from the offspring of BBP-exposed dams indicated increased susceptibility for a $\mathrm{T}_{\mathrm{H}} 2$-mediated immune response, while no significant changes in regulatory $\mathrm{T}$ cell functions were detected. The authors conclude that early exposure to specific phthalates increases susceptibility to the development of allergic asthma mediated by epigenetic changes, leading to altered expression of genes that play a crucial role in immune regulation, contributing not only to asthma development but potentially also to other immune-regulated diseases (Jahreis et al. 2018).

Concerning humans, a significant association between maternal urinary concentrations of the phthalate metabolite mono- $n$-butyl phthalate (MnBP) and increased asthma risk in children has been recently reported (Jahreis et al. 2018).

BPA exposure has been reported as affecting immune cell populations and function from both the innate and adaptive immune system, mainly through agonistic and antagonistic effects on receptors, which modulate the expression of several cytokines, resulting in altered $\mathrm{T}$ cell responses and 
upregulated pro- and anti-inflammatory cytokines and chemokines (Xu et al. 2016). It has also been implicated as a contributor toward the development of type 2 diabetes mellitus, allergy, asthma, and breast cancer due to these immune function altering effects (Xu et al. 2016). However, a lack of studies is still noted.

Assessments have indicated that BPA administered through drinking water results in significant alterations in lymphocyte subpopulations, induction of inflammatory Th-1 type cytokines, and suppression of IL-4 in mice, indicating that BPA induces Th1 polar shifts of transcription factor, resulting in heightened cellular immune responses leading to an exaggerated Th-1 immune response (Weaver et al. 2005). In another study, BPA was administrated to mice through drinking water at $0.015,1.5$, and $30 \mathrm{mg} \mathrm{mL}^{-1}$ for 4 weeks (Youn et al. 2002). A significant production of Th-1 type cytokine (IFN-gamma) was induced while the Th-2 type (IL-4) was suppressed, suggesting stimulation of prolactin production by estrogenic BPA effects, affecting cytokine profiles, leading to imbalanced cellular immune response. In another assessment, mouse pups were exposed both during the prenatal and postnatal periods to $10 \mu \mathrm{g} \mathrm{mL}^{-1}$ of BPA in maternal drinking water displaying an asthma phenotype, while those only exposed in the postnatal period did not exhibit this condition, indicating that environmental exposure to BPA may be linked to the development of airway inflammation and allergic sensitization, although effects are probably modified by the exposure time period duration (Nakajima et al. 2012).

Although BPA has been substituted by BPS, BPA is persistent in sediments and more resistant to biodegradation than BPA in aquatic environments, leading to increased public health concerns (Herrero et al. 2018). Studies in mammals assessing exposure through drinking water, however, are almost non-existent. Of the few available assessments, one study exposed CD-1 mice from gestational day 8 to postnatal day 19 to at $200 \mu \mathrm{g} \mathrm{kg}^{-1}$ bw day $^{-1}$ of BPS and observed alterations in estrogen-responsive genes (Hill et al. 2017), while another evaluated the expression of estrogen receptor and tyrosine hydroxylase immunoreactive cells in two brain regions critical for maternal care in two generations of CD-1 mice and reported significantly increased expression of estrogen receptor in the caudal medial pre-optic area (cMPOA) that was significantly increased when female F0 were exposed to a BPS dose of $200 \mu \mathrm{g} \mathrm{kg}^{-1}$ bw day ${ }^{-1}$, but the same phenomenon was not found in F1 generation (Catanese and Vandenberg 2017). No assessments specifically assessing more general immune responses, such as cytokines, however, are available for BPS.

\section{Health risks associated to disinfectants and cleaning products}

The coronavirus pandemic has completely changed our way of life, and the fear of COVID-19 spread has introduced a more frequent use of chemicals and disinfectants. Most of the products used to disinfect against COVID-19 meeting EPA criteria contain the active ingredient quaternary ammonium (quats) (EPA 2020). Other active ingredients contained in mixtures are hydrogen peroxide, isopropanol, ethanol, sodium hypochlorite, octanoic acid, dodecylbenzenesulfonic acid, chlorine dioxide, phenolics, triethylene glycol, L-lactic acid, dichloroisocyanurate dihydrate glycolic acid, or hypochlorous acid. Some of these compounds, for example, the mixture of quaternary quats and sodium hypochlorite (bleach), have been shown to cause negative health effects when used regularly, especially since adequate use requires protection (gloves, good ventilation), something that people do not usually know about.

Longitudinal studies have shown that occupational exposures to cleaning agents, such as quats, results in a higher proportion of asthma cases in adults (Kogevinas et al. 2007; Obadia et al. 2009). Another study has found that the exposure of women through occupational and/or regular cleaning activities at home result in accelerated declines of lung function, which could represent long-term respiratory health problems (Svanes et al. 2018).

A recent study performed in the USA concerning female nurse exposure to specific disinfectants, such as glutaraldehyde (a strong disinfectant used for medical instruments), hydrogen peroxide, bleach, alcohol, and quats (used for lowlevel disinfection of surfaces such as floors and furniture), found that nurses were associated with an increased risk of chronic obstructive pulmonary disease (Dumas et al. 2019). These findings indicate concrete evidence of respiratory diseases due to disinfectant exposure. Although the importance and need for proper disinfection procedures in hospitals, especially during the COVID-19 pandemic, is clear, the health risks associated with cleaning product exposure should be considered.

\section{Conclusions and required future studies}

Due to the current need to address and understand the impact of different environmental exposures regarding COVID-19, relevant contaminants in drinking water, including metals, PFAS, and plasticizers, according to previously reported immunotoxicity, may raise potential concerns related to COVID-19 respiratory symptoms. Epidemiological studies are still required to evaluate potential synergistic effect between environmental pollutants and the virus. Previous studies have reported that, in addition to affecting the immune response, some compounds can also increase pathogen virulence or resistant to antibiotics, such as, for example, correlations between $\mathrm{Pb}$ exposure and greater detection of methicillin-resistant Staphylococcus aureus (MRSA) (Eggers et al. 2018). Research on PFAS has also demonstrated reduced 
immune responses to vaccines in a community from the Faroe Islands (Grandjean et al. 2017). Therefore, the presence of pollutants in drinking water could be an issue even after a vaccine is discovered for COVID-19.

Studies on the ecological and environmental impact of the increased amount of plastic and other wastes being produced are certainly warranted, to evaluate risks to aquatic organisms and humans. Special attention to the respiratory issues associated to the use of cleaning (disinfectants) products is imperative, highlighting the need for stricter guidelines on their safety usage in both the healthcare environment and at home.

The selected persistent and toxic compounds and health effects discussed herein encompass only a small fraction of the endocrine disruptor contaminants possibly present in drinking water, as other pollutants, such as pesticides, herbicides, polychlorinated biphenyls (PCBs), polycyclic aromatic hydrocarbon (PAHs), and polybrominated diphenyl ethers (PBDE), as well as emerging contaminants, including pharmaceuticals, personal care products, disinfection by-products and metabolites, and transformation products, have also been implicated in immunotoxicity responses. Therefore, the health risks associated with the present of contaminants in drinking water, especially long-term exposures, are of paramount concern, and studies focusing on the effects of mixtures of these compounds are still lacking.

Acknowledgments This is contribution number 988 from the Southeast Environmental Research Center in the Institute of Environment at Florida International University.

Authors' contributions Natalia Soares Quinete: conceptualization; resources; investigation; validation; data curation; formal analysis; project administration; supervision; writing — original draft; writing — draft reviewing. Rachel Ann Hauser-Davis: conceptualization; resources; investigation; validation; data curation; formal analysis; project administration; supervision; writing — original draft; writing — draft reviewing.

Data availability Not applicable.

\section{Compliance with ethical standards}

Ethical approval Not applicable.

Consent to participate Not applicable.

Consent to publish Not applicable.

Competing interests The authors declare that they have no competing interests.

\section{References}

ATSDR (2002) Toxicological profile for lead. ATSDR's Toxicol Profiles. https://doi.org/10.1201/9781420061888_ch106
Bodin J, Groeng EC, Andreassen M, Dirven H, Nygaard UC (2016) Exposure to perfluoroundecanoic acid (PFUnDA) accelerates insulitis development in a mouse model of type 1 diabetes. Toxicol Reports 3:664-672. https://doi.org/10.1016/j.toxrep.2016. 08.009

Bolong N, Ismail AF, Salim MR, Matsuura T (2009) A review of the effects of emerging contaminants in wastewater and options for their removal. Desalination. 239:229-246. https://doi.org/10.1016/j. desal.2008.03.020

Braun JM, Sathyanarayana S, Hauser R (2013) Phthalate exposure and children's health. Curr Opin Pediatr

Bucher JR (2007) NTP toxicity studies of sodium dichromate dihydrate (CAS No. 7789-12-0) administered in drinking water to male and female $\mathrm{F} 344 / \mathrm{N}$ rats and $\mathrm{B} 6 \mathrm{C} 3 \mathrm{~F} 1$ mice and male BALB/c and am3C57BL/6 mice. Toxic Rep Ser

Buser MC, Murray HE, Scinicariello F (2014) Age and sex differences in childhood and adulthood obesity association with phthalates: analyses of NHANES 2007-2010. Int J Hyg Environ Health 217:687694. https://doi.org/10.1016/j.ijheh.2014.02.005

Cardenas A, Smit E, Andres Houseman E et al (2015) Arsenic exposure and prevalence of the varicella zoster virus in the United States: NHANES (2003-2004 and 2009-2010). Environ Health Perspect 123:590-596. https://doi.org/10.1289/ehp.1408731

Cardenas A, Smit E, Welch BM, Bethel J, Kile ML (2018) Cross sectional association of arsenic and seroprevalence of hepatitis B infection in the United States (NHANES 2003-2014). Environ Res 166:570576. https://doi.org/10.1016/j.envres.2018.06.023

Catanese MC, Vandenberg LN (2017) Bisphenol S (BPS) alters maternal behavior and brain in mice exposed during pregnancy/lactation and their daughters. Endocrinology 158:516-530. https://doi.org/10. 1210/en.2016-1723

Chakrabarty S, Sarma HP (2011) Heavy metal contamination of drinking water in Kamrup district, Assam, India. Environ Monit Assess 179: 479-486. https://doi.org/10.1007/s10661-010-1750-7

Chan JFW, Yuan S, Kok KH, To KKW, Chu H, Yang J, Xing F, Liu J, Yip CCY, Poon RWS, Tsoi HW, Lo SKF, Chan KH, Poon VKM, Chan WM, Ip JD, Cai JP, Cheng VCC, Chen H, Hui CKM, Yuen KY (2020) A familial cluster of pneumonia associated with the 2019 novel coronavirus indicating person-to-person transmission: a study of a family cluster. Lancet. 395:514-523. https://doi.org/10.1016/ S0140-6736(20)30154-9

Clara M, Gans O, Weiss S, Sanz-Escribano D, Scharf S, Scheffknecht C (2009) Perfluorinated alkylated substances in the aquatic environment: an Austrian case study. Water Res 43:4760-4768. https://doi. org/10.1016/j.watres.2009.08.004

Crone BC, Speth TF, Wahman DG, Smith SJ, Abulikemu G, Kleiner EJ, Pressman JG (2019) Occurrence of per- and polyfluoroalkyl substances (PFAS) in source water and their treatment in drinking water. Crit Rev Environ Sci Technol 49:2359-2396. https://doi.org/10. 1080/10643389.2019.1614848

De Toni L, Radu CM, Sabovic I, Di Nisio A, Dall'Acqua S, Guidolin D, Spampinato S, Campello E, Simioni P, Foresta C (2020) Increased cardiovascular risk associated with chemical sensitivity to perfluoro-octanoic acid: role of impaired platelet aggregation. Int J Mol Sci 21(2):399. https://doi.org/10.3390/ijms21020399

Diamanti-Kandarakis E, Bourguignon JP, Giudice LC, Hauser R, Prins GS, Soto AM, Zoeller RT, Gore AC (2009) Endocrine-disrupting chemicals: an Endocrine Society scientific statement. Endocr Rev 30:293-342. https://doi.org/10.1210/er.2009-0002

Díaz Padín N, Rodríguez Fourquet, Martínez Castillo YC, Gardinali P, Soares Quinete N (2019) Cuantificación de los ftalatos en los sedimentos de la Reserva Natural Humedal Punta Tuna en Maunabo, Puerto Rico. Mangl América 112-123

Dong W, Simeonova PP, Gallucci R, Matheson J, Flood L, Wang S, Hubbs A, Luster MI (1998) Toxic metals stimulate inflammatory cytokines in hepatocytes through oxidative stress mechanisms. 
Toxicol Appl Pharmacol 151:359-366. https://doi.org/10.1006/ taap.1998.8481

Dong GH, Tung KY, Tsai CH, Liu MM, Wang D, Liu W, Jin YH, Hsieh WS, Lee YL, Chen PC (2013) Serum polyfluoroalkyl concentrations, asthma outcomes, and immunological markers in a casecontrol study of Taiwanese children. Environ Health Perspect 121: 507-513. https://doi.org/10.1289/ehp.1205351

Dumas O, Varraso R, Boggs KM, Quinot C, Zock JP, Henneberger PK, Speizer FE, le Moual N, Camargo CA Jr (2019) Association of occupational exposure to disinfectants with incidence of chronic obstructive pulmonary disease among US female nurses. JAMA Netw Open 2:e1913563. https://doi.org/10.1001/ jamanetworkopen.2019.13563

Duty SM, Silva MJ, Barr DB, Brock J, Ryan L, Chen Z, Herrick R, Christiani D, Hauser R (2003) Phthalate exposure and human parameters. Epidemiology. 14:269-277. https://doi.org/10.1097/ 00001648-200305000-00005

Eggers S, Safdar N, Malecki KM (2018) Heavy metal exposure and nasal Staphylococcus aureus colonization: analysis of the National Health and nutrition examination survey (NHANES). Environ Health 17:2. https://doi.org/10.1186/s12940-017-0349-7

Elfland C, Paolo S, Marc E (2010) Lead-contaminated water from brass plumbing devices in new buildings. J / Am Water Work Assoc 102: 66-76. https://doi.org/10.1002/j.1551-8833.2010.tb11340.x

EPA (2009) Provisional health advisories for perfluorooctanoic acid (PFOA) and perfluorooctane sulfonate (PFOS). Environ Prot

EPA (2018a) National primary drinking water regulations. In: Gr. Water Drink. Water

EPA (2018b) Basic information about nonpoint source (NPS) pollution. United States Environ. Prot. Agency

EPA (2020) List N : products with emerging viral pathogens and human coronavirus claims for use against SARS-CoV-2. Environ Prot Agency

Erythropel HC, Maric M, Nicell JA, Leask RL, Yargeau V (2014) Leaching of the plasticizer di(2-ethylhexyl) phthalate (DEHP) from plastic containers and the question of human exposure. Appl Microbiol Biotechnol 98:9967-9981

Fair PA, Driscoll E, Mollenhauer MAM, Bradshaw SG, Yun SH, Kannan K, Bossart GD, Keil DE, Peden-Adams MM (2011) Effects of environmentally-relevant levels of perfluorooctane sulfonate on clinical parameters and immunological functions in $\mathrm{B} 6 \mathrm{C} 3 \mathrm{~F} 1$ mice. J Immunotoxicol 8:17-29. https://doi.org/10.3109/1547691X.2010. 527868

Farzan SF, Karagas MR, Chen Y (2013) In utero and early life arsenic exposure in relation to long-term health and disease. Toxicol Appl Pharmacol 272:384-390. https://doi.org/10.1016/j.taap.2013.06. 030

Farzan SF, Li Z, Korrick SA, Spiegelman D, Enelow R, Nadeau K, Baker E, Karagas MR (2016) Infant infections and respiratory symptoms in relation to in utero arsenic exposure in a U.S. cohort. Environ Health Perspect 124:840-847. https://doi.org/10.1289/ehp.1409282

Farzan SF, Howe CG, Chen Y, Gilbert-Diamond D, Cottingham KL, Jackson BP, Weinstein AR, Karagas MR (2018) Prenatal lead exposure and elevated blood pressure in children. Environ Int $121(\mathrm{Pt}$ 2):1289-1296. https://doi.org/10.1016/j.envint.2018.10.049

Flanagan S, Johnston R, Zheng Y (2012) Arsenic in tube well water in Bangladesh: health and economic impacts and implications for arsenic mitigation. Bull World Health Organ 90:839-846. https://doi. org/10.2471/blt.11.101253

Forbes (2020) Ten areas where COVID-19 responses have increased environmental risks. In: April 16th

Forsyth DS, Jay B (1997) Organotin leachates in drinking water from chlorinated poly(vinyl chloride) (CPVC) pipe. Appl Organomet Chem 11:551-558. https://doi.org/10.1002/(SICI)10990739(199707)11:7<551::AID-AOC606>3.0.CO;2-0
Francis O, Natalia Q, Anke M, et al (2008) Perfluorooctanoic acid and perfluorooctane sulfonate in Nile Perch and tilapia from gulf of Lake Victoria

Frederiksen H, Sørensen K, Mouritsen A, Aksglaede L, Hagen CP, Petersen JH, Skakkebaek NE, Andersson AM, Juul A (2012) High urinary phthalate concentration associated with delayed pubarche in girls. Int J Androl 35:216-226. https://doi.org/10.1111/j.1365-2605. 2012.01260.x

Ganesan S, Vasudevan N (2015) Impacts of perfluorinated compounds on human health. Bull Environ Pharmacol Life Sci 4:183-191

Garrett RG (2000) Natural sources of metals to the environment. Hum Ecol Risk Assess 6:945-963. https://doi.org/10.1080/ 10807030091124383

Goebel C, Flohé SB, Kirchhoff K, Herder C, Kolb H (2000) Orally administered lead chloride induces bias of mucosal immunity. Cytokine 12:1414-1418. https://doi.org/10.1006/cyto.2000.0708

Grandjean P, Heilmann C, Weihe P, Nielsen F, Mogensen UB, Timmermann A, Budtz-Jørgensen E (2017) Estimated exposures to perfluorinated compounds in infancy predict attenuated vaccine antibody concentrations at age 5-years. J Immunotoxicol 14:188195. https://doi.org/10.1080/1547691X.2017.1360968

Granum B, Haug LS, Namork E, Stølevik SB, Thomsen C, Aaberge IS, van Loveren H, Løvik M, Nygaard UC (2013) Pre-natal exposure to perfluoroalkyl substances may be associated with altered vaccine antibody levels and immune-related health outcomes in early childhood. J Immunotoxicol 10:373-379. https://doi.org/10.3109/ $1547691 X .2012 .755580$

Gu J, Han B, Wang J (2020) COVID-19: gastrointestinal manifestations and potential fecal-oral transmission. Gastroenterology. 158:15181519. https://doi.org/10.1053/j.gastro.2020.02.054

Haefliger P, Mathieu-Nolf M, Lociciro S, Ndiaye C, Coly M, Diouf A, Faye AL, Sow A, Tempowski J, Pronczuk J, Junior APF, Bertollini R, Neira M (2009) Mass lead intoxication from informal used leadacid battery recycling in Dakar, Senegal. Environ Health Perspect 117:1535-1540. https://doi.org/10.1289/ehp.0900696

Haghmorad D, Amini AA, Mahmoudi MB, Rastin M, Hosseini M, Mahmoudi M (2014) Pregnancy level of estrogen attenuates experimental autoimmune encephalomyelitis in both ovariectomized and pregnant C57BL/6 mice through expansion of Treg and Th2 cells. J Neuroimmunol 277:85-95. https://doi.org/10.1016/j.jneuroim. 2014.10.004

Hansen JF, Bendtzen K, Boas M, et al (2015) Influence of phthalates on cytokine production in monocytes and macrophages: a systematic review of experimental trials. PLoS One

Haultail (2020) Yet another consequence of the pandemic: more plastic waste

Herrero Ó, Aquilino M, Sánchez-Argüello P, Planelló R (2018) The BPA-substitute bisphenol $\mathrm{S}$ alters the transcription of genes related to endocrine, stress response and biotransformation pathways in the aquatic midge Chironomus riparius (Diptera, Chironomidae). PLoS One 13:e0193387. https://doi.org/10.1371/journal.pone.0193387

Hill CE, Sapouckey SA, Suvorov A, Vandenberg LN (2017) Developmental exposures to bisphenol S, a BPA replacement, alter estrogen-responsiveness of the female reproductive tract: a pilot study. Cogent Med 4(1):1317690. https://doi.org/10.1080/ 2331205x.2017.1317690

Hiroi H, TSUTSUMI O, MOMOEDA M et al (1999) Differential interactions of bisphenol a and 17beta-estradiol with estrogen receptor alpha (ERalpha) and ERbeta. Endocr J 46:773-778. https://doi.org/ 10.1507/endocrj.46.773

Holt M (2000) Sources of chemical contaminants and routes into freshwater environment. Food Chem Toxicol 38(S):21-27

Hoppin JA, Jaramillo R, London SJ, et al (2013) Phthalate exposure and allergy in the U.S. population: results from NHANES 2005-2006. Environ Health Perspect. https://doi.org/10.1289/ehp.1206211 
Howard G, Bartram J, Pedley S, et al (2006) Groundwater and public health. In: Protecting groundwater for health: managing the quality of drinking-water sources. p 697

$\mathrm{Hu} \mathrm{XC}$, Andrews DQ, Lindstrom AB, et al (2016) Detection of poly- and perfluoroalkyl substances (PFASs) in U.S. drinking water linked to industrial sites, military fire training areas, and wastewater treatment plants. Environ Sci Technol Lett. https://doi.org/10.1021/acs.estlett. $6 \mathrm{~b} 00260$

Huang C, Wang Y, Li X, Ren L, Zhao J, Hu Y, Zhang L, Fan G, Xu J, Gu X, Cheng Z, Yu T, Xia J, Wei Y, Wu W, Xie X, Yin W, Li H, Liu M, Xiao Y, Gao H, Guo L, Xie J, Wang G, Jiang R, Gao Z, Jin Q, Wang J, Cao B (2020) Clinical features of patients infected with 2019 novel coronavirus in Wuhan, China. Lancet 395:497-506. https://doi.org/10.1016/S0140-6736(20)30183-5

Huffpost (2018) China no longer wants your trash. Here's why that's potentially disastrous

Humblet O, Diaz-Ramirez LG, Balmes JR, Pinney SM, Hiatt RA (2014) Perfluoroalkyl chemicals and asthma among children 12-19 years of age: Nhanes (1999-2008). Environ Health Perspect 122:1129-1133. https://doi.org/10.1289/ehp.1306606

IARC (2006) Inorganic and organic lead compounds. IARC Monogr Eval Carcinog Risks Hum 87:

Imanishi S, Manabe N, Nishizawa $\mathrm{H}$ et al (2003) Effects of oral exposure of bisphenol a on mRNA expression of nuclear receptors in murine placentae assessed by DNA microarray. J Reprod Dev 49:329-336. https://doi.org/10.1262/jrd.49.329

Jahreis S, Trump S, Bauer M, Bauer T, Thürmann L, Feltens R, Wang Q, Gu L, Grützmann K, Röder S, Averbeck M, Weichenhan D, Plass C, Sack U, Borte M, Dubourg V, Schüürmann G, Simon JC, von Bergen M, Hackermüller J, Eils R, Lehmann I, Polte T (2018) Maternal phthalate exposure promotes allergic airway inflammation over 2 generations through epigenetic modifications. J Allergy Clin Immunol 141:741-753. https://doi.org/10.1016/j.jaci.2017.03.017

Jin Y, Liu L, Zhang S, Tao B, Tao R, He X, Qu L, Huang J, Wang X, Fu Z (2016) Chromium alters lipopolysaccharide-induced inflammatory responses both in vivo and in vitro. Chemosphere. 148:436-443. https://doi.org/10.1016/j.chemosphere.2016.01.057

Kannan K, Corsolini S, Falandysz J, Fillmann G, Kumar KS, Loganathan BG, Mohd MA, Olivero J, Wouwe NV, Yang JH, Aldous KM (2004) Perfluorooctanesulfonate and related fluorochemicals in human blood from several countries. Environ Sci Technol. 38:44894495. https://doi.org/10.1021/es0493446

Keller JM, Kannan K, Taniyasu S, Yamashita N, Day RD, Arendt MD, Segars AL, Kucklick JR (2005) Perfluorinated compounds in the plasma of loggerhead and Kemp's ridley sea turtles from the southeastern coast of the United States. Environ Sci Technol 39:91019108. https://doi.org/10.1021/es050690c

Kharrazian D (2014) The potential roles of bisphenol A (BPA) pathogenesis in autoimmunity. Autoimmune Dis

Khublaryan MG (2009) Surface waters: rivers, streams, lakes, and wetlands. In: Khublaryan MG (ed) Types and properties of water, 1st edn. pp 79-94

Kogevinas M, Zock JP, Jarvis D, Kromhout H, Lillienberg L, Plana E, Radon K, Torén K, Alliksoo A, Benke G, Blanc PD, DahlmanHoglund A, D'Errico A, Héry M, Kennedy S, Kunzli N, Leynaert B, Mirabelli MC, Muniozguren N, Norbäck D, Olivieri M, Payo F, Villani S, van Sprundel M, Urrutia I, Wieslander G, Sunyer J, Antó JM (2007) Exposure to substances in the workplace and new-onset asthma: an international prospective population-based study (ECRHS-II). Lancet. 370:336-341. https://doi.org/10.1016/S01406736(07)61164-7

Kvietkauskaite R, Dringeliene A, Markevicius A, Siaurys A, Acaite J (2004) Effect of low copper exposure on the antioxidant system and some immune parameters. Vet Hum Toxicol 46:169-172
Lee JC, Laydon JT, McDonnell PC et al (1994) A protein kinase involved in the regulation of inflammatory cytokine biosynthesis. Nature. 372:739-746. https://doi.org/10.1038/372739a0

Leffel EK, Wolf C, Poklis A, White KL (2003) Drinking water exposure to cadmium, an environmental contaminant, results in the exacerbation of autoimmune disease in the murine model. Toxicology 188: 233-250. https://doi.org/10.1016/S0300-483X(03)00092-1

Levantesi C, Bonadonna L, Briancesco R, Grohmann E, Toze S, Tandoi V (2012) Salmonella in surface and drinking water: occurrence and water-mediated transmission. Food Res Int 45:587-602. https://doi. org/10.1016/j.foodres.2011.06.037

Li WC (2014) Occurrence, sources, and fate of pharmaceuticals in aquatic environment and soil. Environ Pollut 187:193-201

Li S, Zhengyan Z, Rong LI, Hanyun C (2005) Decrease of CD4+ Tlymphocytes in children exposed to environmental lead. Biol Trace Elem Res 105:19-25

Li L, Li HS, Song NN, Chen HM (2013) The immunotoxicity of dibutyl phthalate on the macrophages in mice. Immunopharmacol Immunotoxicol 35:272-281. https://doi.org/10.3109/08923973. 2013.768267

Looker C, Luster MI, Calafat AM, Johnson VJ, Burleson GR, Burleson FG, Fletcher T (2014) Influenza vaccine response in adults exposed to perfluorooctanoate and perfluorooctanesulfonate. Toxicol Sci 138:76-88. https://doi.org/10.1093/toxsci/kft269

Luby SP, Halder AK, Huda TM, Unicomb L, Islam MS, Arnold BF, Johnston RB (2015) Microbiological contamination of drinking water associated with subsequent child diarrhea. Am J Trop Med Hyg 93:904-911. https://doi.org/10.4269/ajtmh.15-0274

Ma Y, Niu R, Sun Z, Wang J, Luo G, Zhang J, Wang J (2012) Inflammatory responses induced by fluoride and arsenic at toxic concentration in rabbit aorta. Arch Toxicol 86:849-856. https:// doi.org/10.1007/s00204-012-0803-9

Mahallawi WH, Khabour OF, Zhang Q, et al (2018) MERS-CoV infection in humans is associated with a pro-inflammatory Th1 and Th17 cytokine profile. Cytokine. https://doi.org/10.1016/j.cyto.2018.01. $025,104,8,13$

Makris KC, Andra SS, Botsaris G (2014) Pipe scales and biofilms in drinking-water distribution systems: undermining finished water quality. Crit Rev Environ Sci Technol 44:1477-1523

Markevičius A, Dringeliene A (2004) Comparison of lead and copper exposure effect on immune cells in mice. Acta Medica Litu 11: $14-18$

McLachlan JA (2001) Environmental signaling: what embryos and evolution teach us about endocrine disrupting chemicals. Endocr Rev 22:319-341

Moody CA, Field JA (2000) Perfluorinated surfactants and the environmental implications of their use in fire-fighting foams. Environ. Sci. Technol. 34:3864-3870

Mørck TJ, Sorda G, Bechi N, Rasmussen BS, Nielsen JB, Ietta F, Rytting E, Mathiesen L, Paulesu L, Knudsen LE (2010) Placental transport and in vitro effects of bisphenol a. Reprod Toxicol 30:131-137. https://doi.org/10.1016/j.reprotox.2010.02.007

Nakajima Y, Goldblum RM, Midoro-Horiuti T (2012) Fetal exposure to bisphenol A as a risk factor for the development of childhood asthma: an animal model study. Environ. Heal. A Glob. Access Sci. Source

National Geographic (2020) Pollution made COVID-19 worse. Now, lockdowns are clearing the air. In: Abril 8th

National Resarch Council (2008) Phthalates and cumulative risk assessment. National Academies Press, Washington, DC

Net S, Sempéré R, Delmont A, Paluselli A, Ouddane B (2015) Occurrence, fate, behavior and ecotoxicological state of phthalates in different environmental matrices. Environ Sci Technol 49:40194035

Nicholls JM, Poon LLM, Lee KC, Ng WF, Lai ST, Leung CY, Chu CM, Hui PK, Mak KL, Lim W, Yan KW, Chan KH, Tsang NC, Guan Y, 
Yuen KY, Malik Peiris JS (2003) Lung pathology of fatal severe acute respiratory syndrome. Lancet. 361:1773-1778. https://doi.org/ 10.1016/S0140-6736(03)13413-7

NRC (1999) Arsenic in drinking water. Washington

Obadia M, Liss GM, Lou W, Purdham J, Tarlo SM (2009) Relationships between asthma and work exposures among non-domestic cleaners in Ontario. Am J Ind Med 52:716-723. https://doi.org/10.1002/ajim. 20730

Onder G, Rezza G, Brusaferro S (2020) Case-fatality rate and characteristics of patients dying in relation to COVID-19 in Italy. JAMA - J Am Med Assoc. in press

Pennings JLA, Jennen DGJ, Nygaard UC, Namork E, Haug LS, van Loveren H, Granum B (2016) Cord blood gene expression supports that prenatal exposure to perfluoroalkyl substances causes depressed immune functionality in early childhood. J Immunotoxicol 13:173180. https://doi.org/10.3109/1547691X.2015.1029147

Prevedouros K, Cousins IT, Buck RC, Korzeniowski SH (2006) Sources, fate and transport of perfluorocarboxylates. Environ Sci Technol 40: 32-44. https://doi.org/10.1021/es0512475

Prompetchara E, Ketloy C, Palaga T (2020) Immune responses in COVID-19 and potential vaccines: lessons learned from SARS and MERS epidemic. Asian Pacific J. allergy Immunol

Qian Q, Li P, Wang T, Zhang J, Yu S, Chen T, Yan L, Song Y, Liu X, Gu Y, Wang Y, Jia G (2013) Alteration of Th1/Th2/Th17 cytokine profile and humoral immune responses associated with chromate exposure. Occup Environ Med 70:697-702. https://doi.org/10. 1136/oemed-2013-101421

Quansah R, Armah FA, Essumang DK, Luginaah I, Clarke E, Marfoh K, Cobbina SJ, Nketiah-Amponsah E, Namujju PB, Obiri S, Dzodzomenyo M (2015) Association of arsenic with adverse pregnancy outcomes/infant mortality: a systematic review and metaanalysis. Environ Health Perspect 123:412-421. https://doi.org/10. 1289/ehp.1307894

Quinete N, Wu Q, Zhang T, Yun SH, Moreira I, Kannan K (2009) Specific profiles of perfluorinated compounds in surface and drinking waters and accumulation in mussels, fish, and dolphins from southeastern Brazil. Chemosphere 77(6):863-9. https://doi.org/10. 1016/j.chemosphere.2009.07.079

Radbin R, Vahedi F, Chamani JK (2014) The influence of drinking-water pollution with heavy metal on the expression of IL- 4 and IFN- $\gamma$ in mice by real-time polymerase chain reaction. Cytotechnology 66: 769-777. https://doi.org/10.1007/s10616-013-9626-7

Rahman A, Vahter M, Ekström EC, Persson LÅ (2011) Arsenic exposure in pregnancy increases the risk of lower respiratory tract infection and diarrhea during infancy in Bangladesh. Environ Health Perspect 119:719-724. https://doi.org/10.1289/ehp.1002265

Ramella M, Boccafoschi F, Bellofatto K, et al (2017) Endothelial MMP-9 drives the inflammatory response in abdominal aortic aneurysm (AAA). Am J Transl Res

Rochester JR (2013) Bisphenol a and human health: a review of the literature. Reprod Toxicol 42:132-155

Rusyn I, Peters J, Cunningham M (2006) Modes of action and speciesspecific effects of di-(2-ethylhexyl)phthalate in the liver. Crit Rev Toxicol 36:459-479

Satarug S, Garrett SH, Sens MA, Sens DA (2010) Cadmium, environmental exposure, and health outcomes. Environ Health Perspect 118:182-190. https://doi.org/10.1289/ehp.0901234

Schaider LA, Balan SA, Blum A, Andrews DQ, Strynar MJ, Dickinson ME, Lunderberg DM, Lang JR, Peaslee GF (2017) Fluorinated compounds in U.S. fast food packaging. Environ Sci Technol Lett 4:105-111. https://doi.org/10.1021/acs.estlett.6b00435

Schettler T, Skakkebæk NE, De Kretser D, Leffers H (2006) Human exposure to phthalates via consumer products. In: International Journal of Andrology

Shehata AS, Mohamed ZAE-R, El-Haleem MRA, Samak MA (2013) Effects of exposure to plasticizers di-(2-ethylhexyl) phthalate and trioctyltrimellitate on the histological structure of adult male albino rats' liver. J Clin Toxicol 03. https://doi.org/10.4172/2161-0495. 1000169

Shertzer HG, Bally MB, Opheim DJ (1985) Inhibition of alveolar macrophage killing by di(2-ethylhexyl)phthalate. Arch Environ Contam Toxicol 14:605-608. https://doi.org/10.1007/BF01055391

Shi Y, Wang Y, Shao C, Huang J, Gan J, Huang X, Bucci E, Piacentini M, Ippolito G, Melino G (2020) COVID-19 infection: the perspectives on immune responses. Cell Death Differ 27:1451-1454. https://doi.org/10.1038/s41418-020-0530-3

Shimabukuro-Vornhagen A, Gödel P, Subklewe M, et al (2018) Cytokine release syndrome. J. Immunother. Cancer

Shipkowski KA, Sheth CM, Smith MJ, Hooth MJ, White KL Jr, Germolec DR (2017) Assessment of immunotoxicity in female Fischer 344/N and Sprague Dawley rats and female B6C3F1 mice exposed to hexavalent chromium via the drinking water. J Immunotoxicol 14:215-227. https://doi.org/10.1080/1547691X. 2017.1394932

Shrivastava R, Upreti RK, Seth PK, Chaturvedi UC (2002) Effects of chromium on the immune system. FEMS Immunol Med Microbiol 34:1-7. https://doi.org/10.1111/j.1574-695X.2002. tb00596.x

Skoczyńska A, Poreba R, Sieradzki A, Andrzejak R, Sieradzka U (2002) The impact of lead and cadmium on the immune system. Med Pr 53: 259-264

Soto-Peña GA, Luna AL, Acosta-Saavedra L, Conde-Moo P, LópezCarrillo L, Cebrián ME, Bastida M, Calderón-Aranda ES, Vega L (2006) Assessment of lymphocyte subpopulations and cytokine secretion in children exposed to arsenic. FASEB J 20:779-781. https:// doi.org/10.1096/fj.05-4860fje

Stahlhut RW, van Wijngaarden E, Dye TD, et al (2007) Concentrations of urinary phthalate metabolites are associated with increased waist circumference and insulin resistance in adult U.S. males. Environ Health Perspect. https://doi.org/10.1289/ehp.9882

Sun Q, Cornelis MC, Townsend MK, Tobias DK, Eliassen AH, Franke AA, Hauser R, Hu FB (2014) Association of urinary concentrations of bisphenol a and phthalate metabolites with risk of type 2 diabetes: a prospective investigation in the nurses' health study (NHS) and NHSII cohorts. Environ Health Perspect 122:616-623. https://doi. org/10.1289/ehp.1307201

Sunderland EM, Hu XC, Dassuncao C, et al (2019) A review of the pathways of human exposure to poly- and perfluoroalkyl substances (PFASs) and present understanding of health effects. J Expo Sci Environ Epidemiol

Svanes Ø, Bertelsen RJ, Lygre SHL, Carsin AE, Antó JM, Forsberg B, García-García JM, Gullón JA, Heinrich J, Holm M, Kogevinas M, Urrutia I, Leynaert B, Moratalla JM, le Moual N, Lytras T, Norbäck D, Nowak D, Olivieri M, Pin I, Probst-Hensch N, Schlünssen V, Sigsgaard T, Skorge TD, Villani S, Jarvis D, Zock JP, Svanes C (2018) Cleaning at home and at work in relation to lung function decline and airway obstruction. Am J Respir Crit Care Med 197: 1157-1163. https://doi.org/10.1164/rccm.201706-1311OC

Ternes TA (1998) Occurrence of drugs in German sewage treatment plants and rivers. Water Res 32:3245-3260. https://doi.org/10. 1016/S0043-1354(98)00099-2

Tolins M, Ruchirawat M, Landrigan P (2014) The developmental neurotoxicity of arsenic: cognitive and behavioral consequences of early life exposure. Ann Glob Heal 80:303-314. https://doi.org/10.1016/j. aogh.2014.09.005

Trivedi M, Mathur M, Johri P, et al (2020) Waste management: a paradigm shift BT - environmental concerns and sustainable development

Turley AE, Zagorski JW, Kennedy RC, Freeborn RA, Bursley JK, Edwards JR, Rockwell CE (2019) Chronic low-level cadmium exposure in rats affects cytokine production by activated $\mathrm{T}$ cells. 
Toxicol Res (Camb) 8:227-237. https://doi.org/10.1039/ c8tx00194d

Upson K, Sathyanarayana S, De Roos AJ et al (2013) Phthalates and risk of endometriosis. Environ Res 126:91-97. https://doi.org/10.1016/j. envres.2013.07.003

Wang, Zhu H, Kannan K (2019) A review of biomonitoring of phthalate exposures. Toxics

Wang B, Duan X, Feng W, He J, Cao S, Liu S, Shi D, Wang H, Wu F (2019) Health risks to metals in multimedia via ingestion pathway for children in a typical urban area of China. Chemosphere 226:381387. https://doi.org/10.1016/j.chemosphere.2019.03.158

Wardoyo P, Geddie J (2020) Mass disinfections to combat coronavirus pose another health hazard. In: Reuters

Weaver A, Da Silva AG, Nuttall RK et al (2005) An elevated matrix metalloproteinase (MMP) in an animal model of multiple sclerosis is protective by affecting Th1/Th2 polarization. FASEB J 19:16681670. https://doi.org/10.1096/fj.04-2030fje

Wei Z, Song L, Wei J, Chen T, Chen J, Lin Y, Xia W, Xu B, Li X, Chen X, Li Y, Xu S (2012) Maternal exposure to di-(2ethylhexyl)phthalate alters kidney development through the reninangiotensin system in offspring. Toxicol Lett 212:212-221. https:// doi.org/10.1016/j.toxlet.2012.05.023

WHO (2003) Chromium in drinking-water

WHO (2004) Di(2-ethylhexyl)adipate in drinking-water. Background document for development of WHO guidelines for drinking-water quality

WHO (2011a) Lead in drinking-water - background document for development of WHO guidelines for drinking-water quality

WHO (2011b) Cadmium in drinking-water - background document for development of WHO guidelines for drinking-water quality

WHO (2011c) Guidelines for drinking-water quality. World Health 1: 183. https://doi.org/10.1016/S1462-0758(00)00006-6

WHO (2016) Protecting surface water for health identifying, assessing and managing drinking-water quality risks in surface-water catchments. WHO

Wilbur S, Abadin H, Fay M, et al (2012) Toxicological profile for chromium

Wong CK, Lam CWK, Wu AKL et al (2004) Plasma inflammatory cytokines and chemokines in severe acute respiratory syndrome. Clin Exp Immunol 136:95-103. https://doi.org/10.1111/j.13652249.2004.02415.x

Wu F, Zhao S, Yu B, Chen YM, Wang W, Song ZG, Hu Y, Tao ZW, Tian JH, Pei YY, Yuan ML, Zhang YL, Dai FH, Liu Y, Wang QM,
Zheng JJ, Xu L, Holmes EC, Zhang YZ (2020) A new coronavirus associated with human respiratory disease in China. Nature. 579: 265-269. https://doi.org/10.1038/s41586-020-2008-3

Xu J, Huang G, Guo TL (2016) Developmental bisphenol a exposure modulates immune-related diseases. Toxics

Yoshino S, Yamaki K, Yanagisawa R, Takano H, Hayashi H, Mori Y (2003) Effects of bisphenol a on antigen-specific antibody production, proliferative responses of lymphoid cells, and TH1 and TH2 immune responses in mice. Br J Pharmacol 138:1271-1276. https:// doi.org/10.1038/sj.bjp.0705166

Youn JY, Park HY, Lee JW et al (2002) Evaluation of the immune response following exposure of mice to bisphenol a: induction of Th1 cytokine and prolactin by BPA exposure in the mouse spleen cells. Arch Pharm Res 25:946-953. https://doi.org/10.1007/ BF02977018

Zeng XW, Qian Z, Emo B, Vaughn M, Bao J, Qin XD, Zhu Y, Li J, Lee YL, Dong GH (2015) Association of polyfluoroalkyl chemical exposure with serum lipids in children. Sci Total Environ 512-513: 364-370. https://doi.org/10.1016/j.scitotenv.2015.01.042

Zheng L, Dong G-H, Zhang Y-H, Liang ZF, Jin YH, He QC (2011) Type 1 and type 2 cytokines imbalance in adult male C57BL/6 mice following a 7-day oral exposure to perfluorooctanesulfonate (PFOS). J Immunotoxicol 8:30-38. https://doi.org/10.3109/ 1547691X.2010.537287

Zhong SQ, Chen ZX, Kong ML, Xie YQ, Zhou Y, Qin XD, Paul G, Zeng XW, Dong GH (2016) Testosterone-mediated endocrine function and $\mathrm{TH} 1 / \mathrm{TH} 2$ cytokine balance after prenatal exposure to perfluorooctane sulfonate: by sex status. Int J Mol Sci 17(9): 1509. https://doi.org/10.3390/ijms17091509

Zhou F, Yu T, Du R et al (2020) Clinical course and risk factors for mortality of adult inpatients with COVID-19 in Wuhan, China: a retrospective cohort study. Lancet 395:1054-1062. https://doi.org/ 10.1016/S0140-6736(20)30566-3

Zhu Y, Di Qin X, Zeng XW et al (2016) Associations of serum perfluoroalkyl acid levels with T-helper cell-specific cytokines in children: by gender and asthma status. Sci Total Environ 559:166173. https://doi.org/10.1016/j.scitotenv.2016.03.187

Publisher's note Springer Nature remains neutral with regard to jurisdictional claims in published maps and institutional affiliations. 